\title{
The Effect of Denervation on the Degenerative Process of Type I Fibers in the Biceps Brachii Muscle of the Chick
}

\author{
Yoshitaka Ono, Takafumi Goto, Shotaro Nishimura, \\ Hisao Iwamoto and Hitoshi Takahara \\ Labotatory of Functional Anatomy of Domestic \\ Animals, Faculty of Agriculture, Kyushu \\ University, Higashi-ku, Fukuoka-shi 812
}

(Received January 13, 1992)

Key words : denervation, degeneration, fiber type, chick

An intact, healthy and active nerve supply is required for normal muscle growth and function. Denervation is a general procedure to assess correlations between motor nerves and muscle growth. It is well known that denervation leads to a number of functional changes, including fiber atrophy ${ }^{5,20)}$. The influence of denervation of muscle, however, is also different in the developmental stage of animals ${ }^{17)}$.

In a previous study ${ }^{12)}$, we reported that type I fibers of the intact brachial muscles (biceps brachii, scapulotriceps and humerotriceps mucles) showed a degenerative process in early posthatching development. However, it is not known if the degeneration of type I fibers is under the control of the motor nerve. In response to the previous results ${ }^{12)}$, this study was designed to examine what kind of role the motor nerve plays in the degenerative process of type I fibers or in the developmental process of the biceps brachii muscle, by cutting the motor nerve supply to muscles in a chick.

\section{Materials and Methods}

Male White Leghorn chicks were used in this study. Cutting the medianoulnar nerve supply to the biceps brachii muscle ${ }^{21)}$ in 25 chicks was carried out at 1 week of age. Under anaesthesia administered with an intravenous injection of sodium pentobarbitone $(25 \mathrm{mg} / \mathrm{kg}$ of body weight), the skin of the medial brachial part was incised, and the nerve was carefully separated from the adherent vessels and cut apart at the front of the branch supplying the biceps brachii muscle. The cut free ends were sewn to the adjacent skin to prevent reinnervation. At various stages in the experimental period ( $2 \sim 16$ weeks of age), chicks were sacrificed with an overdose of sodium pentobarbitone, and the biceps brachii muscle was supplied for histochemical observation. Whole cross frozen sections $8 \mu \mathrm{m}$ thick were serially obtained from the muscle belly, and stained for myosin ATPase after preincubation at $\mathrm{pH} 4.3$, 4.5 and $10.5^{1,2,18)}$, and hematoxylin and eosin.

鶏上腕二頭筋におけるI型筇線維の消失過程に及ぼす神経切断の影響 : 尾野喜孝・後藤貴文・西村正太郎・岩元 久雄・高原 斉 (九州大学農学部 福岡市東区 812 )

Anim. Sci. Technol. (Jpn.) 63 (8) : 805-808 805 
Muscle fibers were classified into type I and type II according to the terminology of KHAN $^{103}$. The total number of type I fibers was counted out throughout the sectional area under the microscope $(\times 50 \sim 100)$. The diameter was measured on microscopic photographs $(\times 200)$ on 100 fibers of each type. When the number of type I fibers did not reach 100 , the diameter of all type I fibers was measured. The data obtained in this study were compared with those of the previous report ${ }^{12)}$.

\section{Results and Discussion}

As shown in Table 1, the denervated muscle grew until 11 weeks of age, although the growth rate was lower than that of the intact muscle. The growth of the denervated muscle might have been in response to stretch caused by a rapidly growing skeleton, as stated by STEWART ${ }^{17)}$. This interpretation is also assumed by the result that the denervated muscle increased only a little in weight from 11 to 16 weeks of age while skeleton growth was being completed $^{8)}$. Cutting motor nerve had a great influence on the number and diameter of type I fibers. Although the intact muscles entirely lost their type I fibers at 1 week of age, the denervated muscle continued to contain the ones until 16 weeks of age. The number of type I fibers of the denervated muscle at 2 weeks of age almost corresponded to that of the intact muscle at 1 week of age, and decreased gradually from this stage until 16 weeks of age. This result indicates that stopping the activity imposed on type I fibers by the motor nerve delayed the degenerative process of type I fibers.

The diameter of type I fibers in the intact muscle became smaller with age. In contrast to this, tybe I fibers in the denervated muscle continued to grow, but the diameter of each fiber was in a wide range, suggesting that some fibers grew and some fibers passed through the degenerative process, so the total number of type I fibers gradually decreased. Type II fibers also continued to grow even after denervation, but the growth rate was so much slower that the diameter was only $68 \%$ of those in the intact muscle at 16 weeks of age. It has been reported that muscle fibers grow regardless of innervation or denervation under stretch conditions ${ }^{16)}$. Fiber growth in the denervated muscle observed in this study is considered to be caused by the stretch of the growing skeleton. Except for a small number of greatly degenerated type I fibers which seemed to be degenerative, most fibers showed relatively

Table 1. Comparison of the muscle weight, the number of type I fibers and the diameter of type $I$ and type II fibers between the denervated and the intact biceps brachii muscles

\begin{tabular}{|c|c|c|c|c|c|c|c|c|}
\hline \multirow{3}{*}{$\begin{array}{c}\text { Age } \\
\text { (week) }\end{array}$} & \multirow{2}{*}{\multicolumn{2}{|c|}{$\begin{array}{l}\text { Muscle weight } \\
\text { (g) }\end{array}$}} & \multirow{2}{*}{\multicolumn{2}{|c|}{$\begin{array}{l}\text { Number of } \\
\text { type I fiber }\end{array}$}} & \multicolumn{4}{|c|}{ Fiber diameter $(\mu \mathrm{m})$} \\
\hline & & & & & \multicolumn{2}{|c|}{ type I } & \multicolumn{2}{|c|}{ type II } \\
\hline & D. M. & I. $\mathrm{M}$ & D. M. & I. M & D.M. & I. M & D.M. & I. M. \\
\hline 0 & - & $0.02 \pm 0.01$ & - & $401 \pm 124$ & - & $5.1 \pm 0.6$ & - & $5.3 \pm 0.4$ \\
\hline 1 & - & $0.21 \pm 0.01$ & - & $306 \pm 169$ & - & $4.0 \pm 0.6$ & - & $12.2 \pm 1.2$ \\
\hline 2 & $0.19 \pm 0.01$ & $0.27 \pm 0.04$ & $264 \pm 183$ & 0 & $7.7 \pm 1.5$ & - & $13.2 \pm 1.1$ & $17.7 \pm 1.1$ \\
\hline 3 & $0.24 \pm 0.03$ & $0.49 \pm 0.04$ & $236 \pm 151$ & 0 & $8.9 \pm 1.8$ & - & $15.7 \pm 1.6$ & $21.8 \pm 0.4$ \\
\hline 5 & $0.41 \pm 0.02$ & $1.00 \pm 0.07$ & $123 \pm 90$ & 0 & $16.8 \pm 3.7$ & - & $23.3 \pm 3.6$ & $25.3 \pm 0.7$ \\
\hline 11 & $1.30 \pm 0.10$ & - & $107 \pm 68$ & - & $18.4 \pm 2.8$ & - & $22.6 \pm 1.5$ & - \\
\hline 16 & $1.50 \pm 0.10$ & $3.11 \pm 0.15$ & $90 \pm 64$ & 0 & $21.2 \pm 2.8$ & - & $28.1 \pm 3.2$ & $41.3 \pm 2.1$ \\
\hline
\end{tabular}

Means \pm SD, $n=5$. D. M. : denervated muscle. I. M. : intact muscle.

The values of intact muscles shown in the previous study ${ }^{12}$. 
similar diameters until 5 weeks of age, but after this time extremely large and small fibers began to appear. Besides these fibers, elongated angular fibers were also recognized. These changes were seen in both type I and type II fibers. The diameter of large fibers reached around $140 \mu \mathrm{m}$ in extreme cases. Small size fibers which ranged from 10 to $20 \mu \mathrm{m}$ in diameter gathered in clusters. These features are known as atrophic changes caused by denervation $^{33}$. SolA et al. ${ }^{(6)}$ described that forced stretch caused by loading the weight on wing could produce both hypertrophied fibers and small fibers in the denervated muscle. Why such atrophic features were not observed until 5 weeks of age and suddenly appeared at 11 and 16 weeks of age remains obscure. Some factors other than stretch would be relative to that phenomenon. On the other hand, there is much evidence that a substantial increase in the number of satellite cells occurs in the denervated muscle ${ }^{7,13,15)}$. The small fibers seen in the denervated muscle are likely to be new fibers as stated by SolA et al. ${ }^{16)}$.

The peripheral neuron of the motor nerve secretes growth trophic factors on mus$\operatorname{cles}^{4,11,14)}$, and plays an important role in the development and maintaining of muscle function $^{6,19)}$. But there is no report that motor nerves may be concerned with the degenerative process of muscle fibers. In this study, however, type I fibers which were fated to degenerate in the intact muscle were maintained by denervation, suggesting that the motor nerve has some relation with the degenerative process of type I fibers. And it can be said the motor nerve makes functionally useless fibers (type I fibers in the chick biceps brachii muscle) degenerate and develops the muscle whole in a muscle which is suitable for functional demand.

\section{References}

1) Brooke, M.H. and K.K. KaIser, Three 'myosin adenosine triphosphatase' sys- tems : the nature of their $\mathrm{pH}$ lability and sulfhydryl dependence. J. Histochem. Cytochem., 18:670-672. 1970 a.

2) Brooke, M.H. and K.K. Kaiser, Muscle fiber types: how many and what kind? Arch. Neurol., 23 : 369-379. 1970 b.

3) BRumback, R.A. and R.W. LeECH, Color Atlas of Muscle Histochemistry. PSG Publishing Company Inc. Massachusetts. 1984.

4) Gospodarowicz, D., J. Weseman, J.S. MorAn and J. LonDSTrom, Effect of fibroblast growth factor on the division and fusion of bovine myoblasts. J. Cell Biol., $70: 395-402.1976$.

5) Gutmann, E., The Denervated Muscle. 1356. Consultants Bureau. New York. 1962.

6) Hanzlikova, V. and E. Gutmann, Effect of foreign innervation of the androgensensitive levator ani muscle of the rat. $Z$. Zellforsch., 135 : 165-174. 1972.

7) Hess, A, and S. Rosner, The satellite cell bud and myoblast in denervated mammalian muscle fibers. Am. J. Anat., 129: 21-40. 1970.

8) Iwamoto, Н., H. Takahara and M. OkaMoTo, Fundamental studies on the meat production of the domestic fowl VI. Postnatal growth of skeletal muscle, skin, viscera, bone and fatty tissue of barred plymouth rock ehicken. Sci. Bull. Fac. Agr., Kyushu Uni., 29: 151-162. 1975. (Japanese).

9) JAMES, E.B. and M. Yasuda. System Nervosum Peripheriale. in The Nomina Anatomica Avium. (BAUMEL, J.J., A.S. King, A.M.LucAs, J.E. Breazile and H.E. Evans, eds.) 473-503. Academic Press. London. 1979.

10) Khan, M.A., Histochemical characteristics of vertebrate striated muscle: A review. Progr. Histochem. Cytochem., 8: 1-48. 1976.

11) OH, T.H. and G.J. Markelonis, Neurotrophic effects of a protein fraction isolated from peripheral nerves on sheletal muscle in culture. in Muscle Regeneration. (Mauro A., eds.) 419-428. Raven. New York, 1980.

12) Ono, Y, H. Iwamoto and H. Takahara, Degeneration of type I fibers in the chick brachial muscles during the post hatching development. Anim. Sci. Technol. (Jpn.), 


\section{Ono, Goto, Nishimura, Iwamoto and Takahara}

63: 341-348. 1992.

13) ONTELl, M., Muscle satellite cells : a validated technique for light microscopic identification and a quantitative study of changes in their population following denervation. Anat. Rec., 178 : 211-228. 1974.

14) Singer, M., Trophic functions of the neuron. IV. Other trophic systems. Neurotrophic control of limb regeneration in the newt. Ann. NY Acad. Sci., 228: 308321. 1974

15) SNow, M.H., A quantitative ultrastructural analysis of satellite cells in denervated fast and slow muscles of the mouse. Anat. Rec., 207 : 593-604. 1983.

16) Sola, O.M., D.L. Christensen and A.W. MARTIN, Hypertrophy and hyperplasia of adult chicken anterior latissimus dorsi muscles following stretch with and without denervation. Expl. Neurol., 41: 76-100. 1973.

17) Stewart, D.M., Effect of age on the re- sponse of four muscles of the rat to denervation. Am. J. Physiol., 214: 11391146. 1968

18) Suzuki, A., A comparative histochemical study of the masseter muscle of the cattle, sheep, swine, dog, guinea pig and rat. Histochemistry, 51 : 121-131. 1977.

19) Tomanek, R.J., A histochemical study of postnatal differentiation of skeletal muscle with reference to functional overload. Dev. Biol., 42 : 305-314. 1975.

20) Tower, S., Trophic control of non-nervous tissues by the nervous system : a study of muscle and bone innervated from an isolated and quiescent region of spinal cord. J. Comp. Neurol., 67 : 241-267. 1937.

21) Vanden Berge, J.C., Myologia, in The Nomina Anatomica Avium. (BAUMel, J.J., A.S. King, A.M. LuCAS, J.E. Breazlle and H.E. Evans, eds.) 175-219. Academic Press. London. 1979. 